\title{
Beyond Preaching Women: Saudi Dā iȳāt and Their Engagement in the Public Sphere
}

\author{
Laila Makboul \\ Department of Culture Studies and Oriental Languages, University of Oslo, \\ laila.makboul@ikos.uio.no
}

\begin{abstract}
A prevalent notion among researchers working on gender politics in Saudi Arabia is that women's engagement in the public sphere is restricted by the official interpretation of Islam, which only allows women to engage in issues presumed to be "feminine." Based on an anthropological fieldwork exploration of al-dā iyāt al-muthaqqafāt (traditional female preachers belonging to the intellectual sphere in Riyadh), this article challenges this common assumption. It seeks to understand in what ways these women are a part of the public sphere and how this came about. One key factor is how the religious concept of "commanding right and forbidding wrong" has been expanded to adapt to changing circumstances, circumstances that have necessitated women's presence in the public sphere. Examples from prominent intellectual female preachers such as Nawāl al- 'Īd and Ruqayya al-Muhārib demonstrate how leading dā'iyāt in Riyadh engage in issues affecting Saudi society beyond gender-specific issues and encourage women to take a greater part in the public sphere.
\end{abstract}

\section{Introduction}

My awareness of the phenomenon of female preachers in Saudi Arabia came about by mere coincidence. Knowing that the most prolific Twitter users in the Arab world were Saudis, I was curious about knowing who had the most followed Twitter account among women. With over 900,000 followers, the female preacher Nawāl al-' $\bar{l} d$ had the second-most followed account. Al-' '̄d's was a name that up until then had been unknown to me. ${ }^{1}$ This initial inquiry led the way to a deeper exploration of the world of female preachers, da 'iyāt, which took me to Riyadh, where I ended up conducting a year-long ethnographic fieldwork, attending their various activities and lectures between 2015 and 2016. ${ }^{2}$ As I discovered, Nawāl al- 'Īd belongs

\footnotetext{
1 Twitter account @Nawal_Al3eed_. As of June 2015, the most followed female account belonged to the internationally known figure of princess Amīra al-Ṭawīl, former wife of Saudi prince and businessman al-Walīd bin Țalāl.

2 Although this article approaches the subject of female preachers with the aim of understanding this phenomenon in Saudi Arabia, it is important to emphasize that my fieldwork was exclusively conducted in Riyadh. Therefore, the women included in this research are primarily from the central province and may therefore not reflect potential regional variations of $d \bar{a}$ ' $i y \bar{a} t$ muthaqqafāt who, although belonging to the same category of female preachers, may have other positions than those situated in Riyadh. Similarly, this is not to say
} 
to a category of academic female preachers who lecture at various academic and instructional institutions in the daytime, preach in the evenings, and are active in different forums in the public sphere. Some, including al-' $\bar{I} d$, also have their own educational centres, where they provide courses on various subjects but focus on religious knowledge and social awareness. As of June 2017, al- ' $\bar{I} d$ has more than four million Twitter followers, and the number is rising steadily and fast. The popularity and public prominence of these women led me to revisit the literature on Saudi women in search of an explanation as to why they were strikingly absent. Indeed, they could not even be found in entries where one would presume a reference to them, such as in the Oxford Encyclopedia of Islam and Women (on subjects such as the religious authority of women, Saudi Arabia, or Wahhābiya $){ }^{3}$ This invisibility makes Lila AbuLughod's contention, from 1990, that the human sciences have been overly obsessed with "finding resistors and explaining resistance" highly relevant again. ${ }^{4}$ The lack of attention paid to $d \bar{a}$ ' $i y \bar{a} t$, and the fact their role is seen as marginal, may arguably come from their perceived lack of relevance in the study of power and resistance. Women, such as the preachers, who are seen as conforming with either the political order or religious establishment, would therefore, by default, be deemed insignificant.

In this article, I will begin by revisiting relevant literature on female preachers in Saudi Arabia and the role that official religion has had with regards to women's participation in society. I will then trace the historical trajectory of female Islamic activism in Saudi Arabia, suggesting that the introduction of mass public education was an essential factor for women's engagement in the public sphere and from which the female preacher could obtain the necessary intellectual and religious capital to engage in its environment. Finally, I look more closely at the state's contemporary policy of incorporating women into the labour market, and how the female intellectual preachers have responded to these changes. As will be demonstrated, they have adapted to new situations by advocating solutions that allow for female participation in the public sphere and at the same time safeguard the interests of conservative women living according to an envisioned pious lifestyle that is increasingly being challenged. As a case in point, I will examine how these women respond to one of the most pressing issues for Saudi women today: their incorporation into the workforce. By analyzing the discourse of Nawāl al-' $\overline{\mathrm{I}}$, I will shed light on what may be termed "the

that dāi iyāt muthaqqafāt in Riyadh are a homogeneous group. Notwithstanding their differences, those mentioned in this article do have common perspectives and modes of engagement that I here seek to highlight.

${ }^{3}$ See Hilary Kalmbach, "Religious Authority of Women"; Hatoon al-Fassi, "Saudi Arabia"; and Natana J. DeLong-Bas, "Wahhābīyah," all in The Oxford Encyclopedia of Islam and Women, ed. N.J. Delong-Bas, et al. (New York: OUP USA, 2013), doi:10.1093/acref:oiso/9780199764464.001.0001.

${ }^{4}$ Lila Abu-Lughod, "The Romance of Resistance: Tracing Transformations of Power through Bedouin Women," American Ethnologist 17, no. 1 (1990), 41-55, on 41; doi: 10.1525/ae.1990.17.1.02a00030. 
prohibition-production shift" that has taken place and how the opportunities provided by the state have necessitated an adaptive approach to contemporary realities.

\section{Women excluded from the public sphere? Revisiting existing literature}

The politico-religious alliance that Saudi Arabia is based on, dating back to the eighteenthcentury pact between the $\bar{A} l \mathrm{Sa}$ 'u d and the puritanical religious reformer Muhammad b. 'Abd al-Wahhāb (d. 1792), has formed the ideological backbone of the kingdom up to the present. Although the alliance's power balance has been transformed from its revolutionary origins, when religious puritanism served as the ideological justification for the first Saudi dynasty, to its contemporary role as an accommodating religious institution sanctioning the state's needs, ${ }^{5}$ Wahhabism's influence has strongly prevailed in the public sphere. In primary and secondary school, Islamic subjects constitute between 25 and 29 per cent of the curriculum, of which the teachings of Ibn 'Abd al-Wahhāb form the basis of the religious instruction about monotheism $\left(\right.$ tawhìd).$^{6}$ As a result, specific gender roles affected by religious teachings are instilled in schools and subsequently enacted in society. One example of this is provided by social scientist Eleanor Doumato. ${ }^{7}$ In her study, she concludes that women are excluded from the public sphere because Wahhabism does not welcome women as actors on the public stage. ${ }^{8}$ Others, such as anthropologist Madawi al-Rasheed, attribute the alleged exclusion of women from the public sphere to the creation of what she labels religious nationalism, "a politicized religious tradition serving as an umbrella to construct a homogeneous nation out of a fragmented, diverse and plural Arabian society." "In her view, the interaction between the state, religious nationalism, and social and cultural forms of patriarchy has resulted in the exclusion of women, by making women what she calls "symbols of national identity and authenticity." 10 As Al-Rasheed writes,

\footnotetext{
${ }^{5}$ For more on the evolution of Wahhābī 'ulamā' and their relationship to politics, see Abdulaziz H. al-Fahad, "From Exclusivism to Accommodation: Doctrinal and Legal Evolution of Wahhabism," New York University Law Review 79, no. 2 (2004), 486-519, http://www.nyulawreview.org/sites/default/files/pdf/NYULawReview79-2-Al-Fahad.pdf.

${ }^{6}$ The percentage is of exclusively religious subjects and consists of tafsìr, tawhìd, fiqh and hadīth. It does not include other subjects where religious science is also pervasive, such as in gender specific subjects, history, Arabic and social sciences. For a detailed discussion, see my M.A. thesis where I analyzed the religious curriculum in Saudi Arabian schoolbooks and its role in constructing a Saudi national identity (in Norwegian). Laila Makboul, "Tawhid: konstruksjon av én sann islam i saudiarabiske lærebøker : En analyse av saudisk nasjonal identitet gjennom læren om tawhid” (University of Oslo, 2012).

${ }^{7}$ Eleanor Abdella Doumato, "Education in Saudi Arabia: Gender, Jobs and the Price of Religion," in Women and Globalization in the Arab Middle East: Gender, Economy, and Society, eds. Eleanor Abdella Doumato and Marsha Pripstein Posusney (Boulder, Colo: Lynne Rienner, 2003), 240.

8 Ibid., 243.

${ }^{9}$ Madawi al-Rasheed, A Most Masculine State. Gender, Politics and Religion in Saudi Arabia (New York: Cambridge University Press, 2013), 16.

${ }^{10}$ Al-Rasheed, A Most Masculine State, 16, 19.
} 
Wahhabiyya was from the very beginning a project entangled with enforcing the doctrine of commanding right and forbidding wrong. It is this doctrine and its transformation under the auspices of the state that is most important for understanding the historical subordination of women and their persistent exclusion from the public sphere in Saudi Arabia. ${ }^{11}$

For al-Rasheed, therefore, Wahhabism as a tradition of religious knowledge is not a sufficient variable for understanding Saudi women's exclusion in the public sphere; rather, the explanation lies in its entanglement with state power and its transformation as the country's religious nationalism. She defines the latter, drawing on Roger Friedland's definition, as "a form of politicized collective representation, embedded in institutions, the purpose of which is to create a godly community." 12

In her discussion on educated multazimāt (women committed to an Islamic tradition), she acknowledges that some Islamist women do raise topics beyond female-related issues. However, as for the conformist preachers, they "enter the public sphere only as women preaching to other women, thus creating a parallel yet structurally inferior space for women in order to preserve overall male dominance." 13 Although al-Rasheed offers a valuable contribution to the understudied topic of female preachers in Saudi Arabia, her interpretation of ihtisā $b^{14}$ risks fossilizing the concept by not acknowledging the potential for the doctrine's expansion and adaptation. As will be argued in this paper, the female preachers entered the public sphere through the contextual interpretation of ihtisā $b .{ }^{15}$

In addition to al-Rasheed's study, the work of anthropologist Amélie Le Renard may be considered the closest available literature dealing with contemporary traditional female

\footnotetext{
${ }^{11}$ Ibid., 46-47.

12 Cited in Al-Rasheed, A Most Masculine State, 16. See also Roger Friedland, "Religious Nationalism and the Problem of Collective Representation," Annual Review of Sociology 27 (2001), 125-52, http://www.jstor.org/stable/2678617.

${ }^{13}$ Ibid., 248

${ }^{14}$ Ihtis $\bar{a} b$ is the verbal noun of the active participle muhtasib, the person who carries out the doctrine of commanding right and forbidding wrong (al-amr bi-l-ma 'rüf wa-l-nahy 'an al-munkar). It is the most commonly used term for the civil performance of this instruction. Another term used is hisba, which usually applies to the institutionalization of this doctrine. In Saudi Arabia, hisba often refers to the governmental Committee for the Promotion of Virtue and the Prevention of Vice (CPVPV). However, as Michael Cook explains, hisba has also been used by some classical scholars such as Abū Hāmid al-Ghazālī as a general term for commanding right and forbidding wrong. Michael A. Cook, Commanding Right and Forbidding Wrong in Islamic Thought (Cambridge: Cambridge University Press, 2000), 447-49.

${ }^{15}$ In her book A Most Masculine State, al-Rasheed dedicates a whole chapter to women preachers and female Islamic activists. Among other important insights, such as her introduction of important female figures and their literary production, she demonstrates the importance of education in attaining their advent in the public sphere. Ibid., 248-51.
} 
preachers in Saudi Arabia to date. ${ }^{16}$ Her article gives informative insights into the rise of female preachers and the different variables that have played an important role in building a reputation as an authoritative preacher. ${ }^{17}$ However, like al-Rasheed, she also concludes that female preachers do not have an impact outside of the female sphere. According to Le Renard, "Saudi female preachers are not considered religious authorities generally, but are instead authorities in a parallel female world." ${ }^{18}$ She ascribes their limitation to what she considers an official Saudi interpretation of Islam, according to which "[m]en are not permitted access to female preachers' image or voice, so women - unlike men — cannot record their lectures on audio or videotapes, or have their own satellite TV programmes. This limits their potential audience. Furthermore, much of their (more accessible) material on the Internet is specifically aimed at women, so may not be attractive to men. ${ }^{19}$ This observation might indeed have been the prevalent situation when Le Renard conducted her fieldwork between 2005 and 2009, but, as the author herself points out, famous preachers such as Ruqayya alMuhāarib and Asmā' al-Ruwayshid did already then participate in different sessions in the King Abdulaziz Center for National Dialogue (KACND), where their talks where transmitted to the overall audience, who comprised both men and women. ${ }^{20}$ Evidently, the fact that these women's voices were supposedly 'awra (or forbidden for men to hear) was not an obstacle to their oral participation. This observation is important for several reasons. As will be shown in greater detail below, the transmission of their oral lectures to the wider public - both men and women - in combination with new technology and an increasingly accommodating political leadership, have been important factors for their growing appearance and prominence in the public sphere. But before moving into this discussion, it is important to map the ideological underpinnings of the $d \bar{a}$ ' $i y \bar{a} t$ in this article.

\section{Female Islamic activism}

Saudi women committed to an Islamic tradition come from different backgrounds with varying ideological orientations. Trying to categorize them is a challenge, for many reasons. First, in the Saudi kingdom, Islam is the prism through which any discourse is filtered, to the extent that even the most liberal thinkers need to comply with it. Second, literature addressing

\footnotetext{
${ }^{16}$ Amélie Le Renard, "From Qur'anic Circles to the Internet: Gender Segregation and the Rise of Female Preachers in Saudi Arabia," in Women, Leadership, and Mosques: Changes in Contemporary Islamic Authority, eds. Masooda Bano and Hilary Kalmbach (Leiden: Brill, 2012), 105-26.

${ }^{17}$ Le Renard identifies knowledge, activism, and charisma as important factors in building the reputation and authority of a female preacher. Ibid, 116.

${ }^{18}$ Ibid., 120.

19 Ibid., 121.

${ }^{20}$ Ibid., 121.
} 
female Islamist activists in Saudi Arabia is scarce. It is therefore difficult to ascertain which trends the different female Islamic activists belong to or whether they are even a part of those trends. Most of the academic literature dealing with Saudi Islamism is written by male researchers with limited access to the female part of the movements, which probably explains the lack of attention to women in their writings. ${ }^{21}$ Third, the polarized public debate in Saudi Arabia on women's role in society has given way to a tendency from both liberals and conservatives to label each other in opposing ideological categories as a way of discrediting each other. One recurring label is surūrì (i.e. to be classified as a part of the surūrī movement, an exclusivist branch of the wider Islamist movement in Saudi Arabia that came into being in the late 1960s). ${ }^{22}$ Another is $i k h w a \bar{n} \bar{\imath}$ (i.e. to be associated with the Muslim Brotherhood - al$i k h w \bar{a} n$ al-muslimūn - movement). ${ }^{23}$ This leads to many speculations that are difficult to verify but that nevertheless place some of the female Islamist preachers into categories with which they do not want to be associated. It became so serious that in March 2014, Nawāl al' $\overline{\mathrm{I}}$, one of the most prominent of the Saudi da 'iyāt, tweeted that she would appoint a lawyer to follow up on the allegations that she was a part of the ikhwāni movement. ${ }^{24}$

The accusations that occurred in 2015, after the Shūrā Council, the Saudi government's main consultative body, voted in favour of amending the Saudi civil status law, are quite telling of this polarized climate. Three female Shūrā members proposed the removal of the gendered term "head of household" ( rabb al-usra) as it was considered discriminatory towards women. Among other limitations, it was said that it prevented women from obtaining their original household register. Both the proposal and the female Shūrā member Latịfa alSha lān met with strong opposition, prompting prominent female preachers such as alMuhārib to accuse the proposal's proponents of running the errands of Western feminist

\footnotetext{
${ }^{21}$ The role of female Islamists is strikingly absent in the scholarly literature on Islam in Saudi Arabia and Saudi Islamism: Mohammed Ayoob and Hasan Kosebalaban, Religion and Politics in Saudi Arabia: Wahhabism and the State (Boulder, Colo.: Lynne Rienner Publishers, 2009); David Dean Commins, The Wahhabi Mission and Saudi Arabia (London, New York: I.B. Tauris, 2006); David Commins, Islam in Saudi Arabia (Ithaca, New York: Cornell University Press, 2015); Thomas Hegghammer, Jihad in Saudi Arabia: Violence and PanIslamism since 1979 (Cambridge, UK: Cambridge University Press, 2010); Stéphane Lacroix, Awakening Islam: The Politics of Religious Dissent in Contemporary Saudi Arabia, trans. George Holoch (Cambridge, Mass.: Harvard University Press, 2011). For example, in his excellent work on the Saudi șahwa movement, Stéphane Lacroix only mentions in passing the role of Suhayla Zayn al-'Ābidīn as "one of the first Sahwi female intellectuals." Lacroix, Awakening Islam, 157. There is no in-depth discussion of her role in the șahwa movement, nor of women's role in general. Instead, they are regarded as being physically and symbolically segregated from the social arena by the Saudi authorities" construction of a "field of women" which limited their actions to issues presumed to be "feminine." Ibid., 21.

22 Ibid., 69

23 'Abdāllah Āl Hayḍa, "Ikhwāniyāt wa-surūriyāt al-sa'ūdiyya ya' bīn tajāwuz zalāmyāt al- 'uqūd al-māḍiya [Saudi Ikhwān̄̄ and Surūrī Women Refuse to Move Beyond the Darkness of Past Decades]," al-'Arab, 12 February 2014, http://alarab.co.uk/?id=15207.

${ }^{24}$ Nawāl al-' $\overline{\mathrm{I}}$, Twitter post, 11 March 2014, https://twitter.com/Nawal_Al3eed /status/443389568763850752.
} 
movements by wanting to remove what in their view was an Islamic prescription. ${ }^{25}$ In what could be interpreted as a counter-attack, al-Sha lān wrote an article two months later warning about the dangers of female members of the surūrī movement, "al-Surūriyāt." 26 As for alMuhārib, she has denied any connection with the movement and has called the accusations a delusion. $^{27}$

One way to address these challenges concerning female preachers is to draw on existing literature covering their male counterparts. By mapping the different Islamic tendencies, I suggest that it is possible to assume that women have also had a presence among these strands. In addition, an analysis of the women's discourse might help to identify from where female preachers such as al-' $\bar{I} d$ and al-Muhārib take inspiration. In his book on the Saudi Islamic Revival (al-șaḥwa al-islāmiyya, or simply șaḥwa), Stéphane Lacroix provides an insightful exploration of the different strands of Salafism in contemporary Saudi Arabia. ${ }^{28}$ On one side of the flank are the absolute loyalists widely known as Jāmiyya or Madkhali (named after their popular scholars Muḥammad Amān al-Jāmī and Rabī' al-Madkhalī). As a counter-movement to the șạwa, they focus on purifying the creed and showing absolute loyalty to the royal family. ${ }^{29}$ Placed in the middle are the traditional Wahhabi scholars who vary in their support of the social and political activism of the șạwa. Included in this category were well-known scholars and former late muftīs such as 'Abd al- 'Azīz b. Bāz and Muhammad b. al-'Uthaymīn. ${ }^{30}$ The other side of the flank is made up of different, often conflicting, political and social trends inspired by the șahwa movement that began in the 1960s and culminated in the 1990s. As a hybridization of the Muslim Brotherhood's political activism and the theology of Wahhabism, the movement consisted of both Bannaist and Qutbist-inspired tendencies. ${ }^{31}$ Today, the movement has been divided into three competing factions: the "new șaḩwa" (who call for moderation and are primarily occupied with social activism), the Islamo-Liberals (who advocate peaceful political constitutional reforms), and the neo-jihādīs (who support al-Qā' ida and openly criticize the Saudi regime). ${ }^{32}$

\footnotetext{
25 Ruqayya al-Muhārib, Twitter $\quad$ post, $\quad 15 \quad$ October 2015 , https://twitter.com/rokaya_mohareb/status/654701385414348802.

${ }^{26}$ Lațīfa al-Sha'lān, "al-Surūriyya...al-buhayra al-ḍiḥla [Surūriyyah...The Lagoon]," al-Hayāt, 8 December 2015, http://www.alhayat.com/Opinion/latafa-alshalan/12632455/الضحلة_السرورينة/البحيرة2016.

${ }^{27}$ Ruqayya al-Muhārib, interview by author, 28 September 2016.

${ }^{28}$ Lacroix, Awakening Islam.

${ }^{29}$ Ibid., 211-15. In a course seminar I attended on how to become a preacher, the audience was taught that one of the most important tasks for a preacher is to be obedient to the ruler, whereupon one of attendees exclaimed that obedience to the ruler is [the same as] obedience to God (ța 'at wali al-amr, ță at Allāh). Dā' iya A, "Kayfa takūnīna dā 'iya [How to become a preacher]," seminar, Riyadh, 1 December 2015.

${ }^{30}$ Lacroix, Awakening Islam, 168-72.

${ }^{31}$ Ibid., 52-53.

${ }^{32}$ Ibid., 241.
} 
Arguably, the female preachers in this article are largely situated within the mainstream Wahhabi tradition but are influenced by the social activism of the moderate strand of the șahwa movement. These women can best be described as traditional intellectual

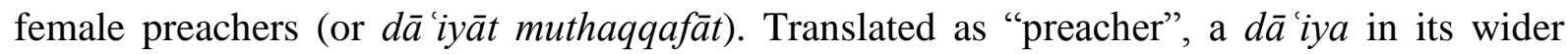
understanding is anyone who, from a religious perspective, shares a (religious) concern for society and whose concern is acknowledged by others. ${ }^{33}$ Although there are no formal requirements, a da' iya is expected to have a minimum of religious knowledge and be able to give good advice to others. By possessing these qualities, the da 'iya must respond to the duty of da'wa, which for her becomes an individual obligation (fard 'ayn) and encompasses everything from sharing religious knowledge with the nearest ones to holding lectures with the wider public. ${ }^{34}$ The muthaqqafāt stand out from other dā 'iyāt in that they belong to both the religious and the intellectual field. The main women in my research all hold a $\mathrm{PhD}$ and teach in universities, in addition to lecturing at religious gatherings and supervising their own religious-intellectual centres. They are always introduced by their educational qualification as duktüra, and are thus distinguished from preachers who do not have the intellectual authority to draw on but are instead simply referred to as a $d \bar{a}$ iya, or ustādha (an entitlement that indicates some higher educational background without specifying). ${ }^{35}$ Intellectual capital is so important for the hierarchical authority of a $d \bar{a}$ 'iya that on more than one occasion, as I was talking about one particular $d \bar{a} ' i y a$, it was pointed out that the dā iya in question did not have a doctorate although she claimed to have one. On another occasion, a preacher who was introduced as ustädha and whose lectures I attended, approached me afterwards to explain that she had started a master's degree in Arabic but had been unable to complete it due to illness. ${ }^{36}$

Intellectual capital also has an important relevance to the rivalry between the more liberal-minded and the Islamists in the social sphere. On a Twitter poll made by Lahā Online, a website and educational centre owned by al-Muhāaib, users were asked whether they believed that intellectual female preachers could lead a national project aimed at uniting women's endeavours regardless of intellectual disagreements among them. ${ }^{37}$ What is interesting about the poll is not so much the result (out of 1,584 voters, 81 per cent answered yes) as the question itself being posed. As Lacroix explains, the category muthaqqaf was,

\footnotetext{
${ }^{33}$ Nūra al-'Umar, interview by author, 30 December 2015.

${ }^{34}$ Ibtisām al-Sa'dūn, interview by author, 28 February 2016.

${ }^{35}$ Other common labels are kātiba (writer/essayist) or akādimiyya (academic) which are commonly used for both liberal and conservative women.

${ }^{36}$ Dā iya A., conversation with author, 1 December 2015.

${ }^{37}$ Lahā Online, Twitter post, 6 December 2015, https://twitter.com/lahaonline/status/673409828899962880.
} 
until the 1980s, largely composed of a "liberal intelligentsia" loyal to the regime, but their dominance would soon be challenged as the Saudi Islamist intellectuals entered the field in the mid-1980s. ${ }^{38}$ The poll is therefore revealing both of how the preachers distinguish themselves from other preachers as being muthaqqafăt and of how they envisage their role as leading the cause of women in the kingdom.

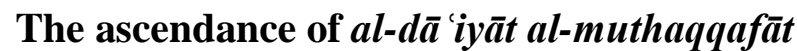

The introduction of mass public education in the 1960s opened up the religious field to women beyond those who were descendants of well-known religious families such as $\bar{A} l$ alShaykh, al-Juraysh, al-Sa d, and al-Nașīf. ${ }^{39}$ New female religious authorities graduated from institutions that had largely been developed by Syrian and Egyptian Muslim Brotherhood members who had sought refuge from the repressive Nasserite and Baathist regimes. While the traditional Salafi scholars were mainly in control of the curriculum on creed ( $a q \bar{i} d a$ ), affiliates of the Brotherhood introduced new religious sciences while Islamizing other subjects. ${ }^{40}$ It is therefore not surprising that the intellectual preachers in this article remained within the traditional strand of Salafism while being influenced by the social and political activism of the șaḥwa.

The intellectual female preachers, like their male counterparts, began their careers in the educational system first as students and later as academics in various universities. Many of them began preaching inside university campuses, where they set up gatherings for memorizing the Qur'an. In Riyadh, many of their organized religious activities first took place at what was then called the Faculty of Education, now Princess Noura University (PNU). Sāra al-Mas 'ūd, ${ }^{41}$ a preacher and the author of a book on how to become a dā iya, ${ }^{42}$ recalls that she started preaching at the age of 19 during her time as an Arabic student at the faculty. ${ }^{43}$ As a testimony to the popularity of religious circles, there were times when she was teaching one hundred students Qur'anic memorization annually inside the campus. ${ }^{44}$ This

\footnotetext{
${ }^{38}$ Lacroix, Awakening Islam, 20.

${ }^{39}$ Al-Rasheed, A Most Masculine State, 255.

${ }^{40}$ Lacroix, Awakening Islam, 45-48.

${ }^{41}$ al-Mas 'ūd, having a B.A. in Arabic, is not considered in this paper as being part of the category al-dā' iyāt almuthaqqafāt who I understand as being women who have at least a higher educational degree in religious sciences. Her opinions on the role of women in the public sphere also sharply diverge from those of the muthaqqafät. Al-Mas 'ūd is nevertheless important to mention as a noteworthy figure in the initial development of the $d a^{\prime} w a$ movement among women. She has also trained women to become $d \bar{a}$ ' $i y a \bar{t}$ for decades, resulting in a book on the same subject being published this year. Sāra al-Mas 'ūd, Kayfa takūninna dā 'iya [How to Become a Preacher] (Riyadh: Dār al-Ṣamīmī Press \& Distribution, 2016).

42 Ibid.

${ }^{43}$ Interview by author, 30 August 2016.

44 Ibid.
} 
took place after the seizure of the Grand Mosque in Mecca in 1979, an incident described by some of the preachers I spoke with as a watershed. Ibtisām al-Sa dūn, an assistant professor at PNU who described herself as one of the first female preachers, along with her sister İmān and al-Muhārib, told me that in addition to being influenced by the șahwa, this incident made her aware of what she described as widespread ignorance (jahl) in Saudi society. Just as alMas' ūd did, al-Sa'dūn also started giving religious lectures, in 1982 in Eastern Province, where she lived during that time, recounting it as an individual endeavour springing from a concern for society and not because they belonged to any of the organized groups (jamā 'ât) during that time, alluding to $i k h w a \bar{a} n \bar{l}$ - and surūrī-affiliated groups. ${ }^{45}$ According to al-Muhāaib, they would listen to cassette sermons of renowned scholar preachers, such as the late grand muftīs Shaykh Ibn 'Uthaymīn and Shaykh Ibn Bāz, and convey their messages in gatherings of women, such as at the Hawdaj market, the first women-only shopping centre in Saudi Arabia. ${ }^{46}$ Women such as al-Muhārib and al-Sa'dūn all pursued education in religious sciences and are today employed in PNU's Islamic department. In addition to her doctoral degree in Hadith, al-Muhārib has been granted religious authority by Shaykh bin Bāz to give fatwās based on her exceptional role in the field of $d a{ }^{i} w a \cdot{ }^{47}$ She is thus highly acknowledged by other women as a muftiyya, a title rarely given to a woman. Testifying to her religious knowledge, she was asked to join the national council of senior 'ulamā', a process that, according to al-Muhārib, is currently pending. ${ }^{48}$ Other Islamic activists of great importance during the same time were women such as Fātima Naṣîn, Suhayla Zayn al-' Ābidīn, and Nūra al-Sa'd. Participating in literary outlets, these women contributed to the public debate on societal, religious, and women-related issues. ${ }^{49}$

Contrary to al-Rasheed's contention that the doctrine of ihtisāb excluded women from the public sphere, in the case of the dā 'iyât al-muthaqqafāt it was exactly this notion that was utilized in order to justify their participation in the public sphere. The importance of $d a$ ' $w a$ as a religious endeavour for both males and females is taught as early as in elementary school. In a fifth-grade textbook on tawhìd, children learn that da wa is regarded as the third pillar of Islam, instructed by God right after the obligation of acquiring correct knowledge of the faith

\footnotetext{
${ }^{45}$ Ibtisām al-Sa'dūn, interview by author, 28 February 2016.

${ }^{46}$ Interview by author, 28 September 2016.

${ }^{47}$ Ibid.

48 Ibid.

${ }^{49}$ Today, only al-Sa 'd and Nașîf are still highly esteemed as preachers in traditional circles. Zayn al- 'Abidīn lost the support of the traditional 'ulam $\bar{a}$ ' after her independent religious reasoning, ijtihād, began to diverge from their opinions. According to her, she was, in the beginning, only echoing the voices of the male 'ulama ' which didn't contain much self-reflection. It wasn't until she received her $\mathrm{PhD}$ from the religious institution of al-Azhar that she began her critical analyses of the interpretation of religious texts, which ultimately led to opposition from the traditional 'ulama '. Interview by author, 21 September 2016.
} 
('ilm) and acting according to this knowledge ('amal). ${ }^{50}$ Traditionally, women's $d a$ 'wa was understood as the work that she undertook in the domestic space as a daughter, wife, and mother. According to Ibn al-'Uthaymīn, the work of religious reformation in society (iṣlāh almujtama ) is divided into two types: the visible, which happens in markets, mosques, and other public spaces and which men undertake, and the work in the home "behind the walls", for which women are responsible. ${ }^{51}$ However, following the rise of the Islamic Revival movement, the understanding of women's responsibility in the field of $d a$ 'wa was expanded to include a much larger platform due to the necessity of keeping up with new needs and possibilities in a changing society. In a book co-authored with Nawāl al- '̄̃d and Fātịma alJārullah, ${ }^{52}$ the prominent Saudi (male) preacher 'Awaḍ al-Qarnī ${ }^{53}$ emphasizes the urgent need to facilitate the participation of women in the field of $d a{ }^{c} w a .{ }^{54} \mathrm{He}$ introduces the subject by referring to the religious prescription of $d a$ ' $w a$ as applying to both men and women, before demonstrating how women have participated in da wa throughout history. He laments the negligence of women in this field, which he blames on the lack of physical and educational facilities, before prescribing different ways of correcting this situation. ${ }^{55}$

Closely connected to the concept of $d a$ 'wa, ihtisāb can be understood as the doctrinal justification of $d a^{\prime} w a$. Studying Egyptian $d \bar{a}$ 'iyāt and their role within the Islamic Revival movement in the 1990s, anthropologist Saba Mahmood argues that al-amr bi-l-ma 'rüf wa-lnahy 'an al-munkar (commanding right and forbidding wrong) is interrelated with da wa in three ways:

Sometimes the terms are used synonymously [...]. At other times, da wa is commonly understood as a kind of vocation [...], while amr bil ma rūf is regarded as a duty that a Muslim undertakes in the context of normal life. Finally, while both can be understood as involving enjoinders to piety, the notion of enjoining as it is used in amr bil ma rūf

\footnotetext{
${ }^{50}$ Makboul, "Tawhid".

${ }^{51}$ Muḥammad S. al-'Uthaymīn, "Dawr al-mar'a fì iṣlāḥ al-mujtama' [the Role of Women in Reforming Society],” (Riyadh: Dār al-Qașīm Press, 1998), 3-4.

52 An associate professor at the Imam University in Riyadh.

53 al-Qarnī has been accused of being a member of the Brotherhood branch of the Sahwa, an allegation he has refuted several times. In an interview with al-Sharq al-Awsat, he denied that the Brotherhood exists as an organization in Saudi Arabia, but he confirmed that their thoughts have had an influence in society, but then just like any other intellectual thought, such as Marxism, Modernism and Liberalism. 'Ubayd al-Suhaymī, "Awaḍ Al-Qarnī: al-Ikhwān al-Muslimūn mawjūdūn fī al-Sa 'ūdiyya ka-tayyār fikrī yu' aththir wa yata' aththar ['Awaḍ al-Qarnī: The Muslim Brotherhood is Present in Saudi Arabia as an Intellectual Current, It Influences and is Influenced]," al-Sharq al-Awsat, $\quad 1 \quad$ June http://archive.aawsat.com/details.asp?issueno=11700\&article=571995/ - .WJO4UWUcvWm.

54 'Awaḍ al-Qarnī, "Wāqi ' al-da 'wa al-nisā'iyya [the Reality of Women Da 'wa],” eds. 'Awaḍ al-Qarnī, Nawāl al- 'İd, and Fațīma al-Jārullah, al-Mar'a wa-l- 'amal al-da' 'awī [The Woman and Da'wa Work] (Riyadh: Waqf Da'wa Foundation, 2006).

${ }^{55}$ Ibid., 7-10.
} 
extends beyond acts of encouragement to the use of force in prohibiting undesirable conduct." $" 56$

The interrelationship between these notions and the encompassing perception of iḥtisāb is highly visible in the debate on women's issues. Malāk al-Juhn̄ī, an academic who also belongs to the category of the muthaqqafät, argues that ihtisāb covers all aspects of a woman's life, including the intellectual, social, economic, and political. ${ }^{57}$ This is because $i h t i s a \bar{b}$, she argues, is a comprehensive concept in Islam that includes all human behaviour. ${ }^{58}$ In her popular book on women's rights, ${ }^{59} \mathrm{Nawa} l$ al- ' $\overline{\mathrm{I}} \mathrm{d}$ even extends the notion of $i h t i s \bar{a} b$ to include women's right to command the ruler to do right and forbid him from wrongdoing. ${ }^{60}$ She argues that ihtisāb is obligatory for both men and women, before concluding that women hence must "command to right and forbid wrong, and she may offer her plight to the rulers and perform her role in al-amr bi-l-ma'rüf wa-l-nahy 'an al-munkar on behalf of the general public, her kinsmen, scholars and seekers of knowledge." ${ }^{61}$ However, it is important to note that she limits the enforcement of women's ihtisāb on men, as would be the case if women were appointed to head CPVPV ${ }^{62}$ This, she writes, is because it would contradict a man's religiously prescribed role as a guardian $(q a w w \bar{a} m)^{63}$ over women. Thus she limits women's capacity in ihtisāb in the public sphere in cases where both men and women are the potential transgressors to the first two meanings explained by Mahmood earlier in this section, and excludes her from the third aspect (of enforcing this command on men).

Al-'İd's religious exegesis gives a vibrant insight into women's role as religious authorities. A common feature in her work is that she not only presents sources that support her arguments but also gives an amount of attention to diverging opinions before arriving at her own conclusion on a given matter. One can derive at least three implications from this methodology. First, she acknowledges the opinions of those who may be in disagreement with her by referring to existing disagreements on the subject. Second, she demonstrates that

\footnotetext{
${ }^{56}$ Saba Mahmood, Politics of Piety: The Islamic Revival and the Feminist Subject (Princeton, N.J.: Princeton University Press, 2012), 59-60.

${ }^{57}$ Malāk al-Juhni, “al-Iḥtisāb fī qaḍāyā al-mar'a: Mafāhīm wa-taṭbīqāṭ [Iḥtisāb in Women Issues: Theory and Practice]," www.malakaljohany.com, 17 March 2014, http://malakaljohany.com/play.php?catsmktba=33.

${ }^{58}$ Ibid.

${ }^{59}$ Competing with male scholars, she was awarded the Prince Nāyif bin 'Abd al- Azīz Āl Sa 'ūd international prize of the Prophet's Sunnah and contemporary Islamic Studies in 2007 for her book "Women's Rights in light of the Prophet's Sunnah."

${ }^{60}$ Nawāl al- 'İd, Huqūq al-mar'a fì daw' al-sunna al-nabawiyya [Women's Rights in Light of the Prophetic Sunnah] (Riyadh: www.nawalaleid.com, 2006), 443-49.

61 Ibid., 449.

62 Ibid., 456.

${ }^{63}$ The notion of qawwām is derived from verse number 34 in chapter 4 of the Quran: "Men are caretakers of women, since Allah has made some of them excel the others, and because of the wealth they have spent." (Taqi Usmani translation).
} 
women, like men, can have religious authority and engage in independent reasoning of holy scriptures $(i j t i h \bar{a} d)$. As a matter of fact, she dedicates parts of her book to arguing that women have the same right to engage in providing fatwa and becoming a muftiyya like men. ${ }^{64}$ Third, her acknowledgement of differences of opinion allows for greater flexibility to adjust opinions to changing circumstances. This was exactly what happened when al- ' $\bar{I} d$ supported the late King 'Abdullāh's decision to appoint women to the Shūrā Council, even when her writings can be understood as discouraging women's presence in the Shūrā. What this shows is that a female preacher's political engagement is contingent upon the opportunities provided by the state, whereby they apply ihtisāb to extend their influence to new spheres. This is evident in the expanding presence of the $d \bar{a}$ ' $i y \bar{a} t$, which has taken place at the same time that the Saudi public sphere has increasingly accommodated women, albeit within a strictly gender-segregated order.

\section{The voice of female preachers under the patronage of the state}

During the past two decades, women have become increasingly visible in the public sphere as growing numbers of educated Saudi women have become active contributors in media outlets and literary production. This development has coincided with wider educational opportunities for women, as many disciplines previously preserved for men have now become available to women. ${ }^{65}$ Saudi women are exceeding men in higher education and make up one-fourth of students studying abroad thanks to the King 'Abdullāh Scholarship Program, which was introduced in 2005. ${ }^{66}$ These improvements are also in line with the official objectives. According to the latest five-year educational development plan, women are to contribute to society's development in various fields and by different means, including through the establishment of organizations for women and women's participation in other specialist

\footnotetext{
${ }^{64}$ al-' $\overline{\mathrm{I}}$, Huqūq al-mar'a fì daw' al-sunna al-nabawiyya, 303-15. This contradicts Le Renard's claim that women cannot become 'ālima and are never considered 'ulamā' or muftīs. Le Renard, "From Qur'anic Circles to the Internet," 113. As demonstrated earlier by the example of al-Muhārib, women can become both 'ālimāt and muftiyyāt.

${ }^{65}$ This has also occurred at the same time as increasing international attention on Saudi women and women elsewhere in the Middle East. Promoting women and minority rights is a common trend among regimes in the region seeking to present a modern image of themselves to the outside world by introducing reforms that do not pose a direct challenge to their authority. In Morocco for example, the King introduced a new family code in 2004, the mudawwana, deriving its name from one of the most authoritative references in Mālikī jurisprudence. The family law was celebrated as a revolution for women's rights in Morocco and a victory against Islamist opposition. Erik German, "Morocco: A Look at Women's Rights 5 Years after Reforms," The World Post, 7 October 2009, http://www.huffingtonpost.com/2009/06/09/morocco-a-look-at-womens_n_213362.html.

66 Afshin Molavi, "King Abdullah: A Saudi Education Revolutionary," Al-Arabiya, 23 January 2015, http://english.alarabiya.net/en/views/news/middle-east/2015/01/23/King-Abdullah-A-Saudi-educationrevolutionary.html.
} 
areas. ${ }^{67}$ Furthermore, the plan aims to expand women's participation in the economy by absorbing the large supply of women labourers, and widen the options available to women in the scientific, technical, and professional disciplines. The expansion of the role of women in developing the state has been reaffirmed in the announcement of Saudi Vision 2030, an extensive economic reform plan launched in 2016 with the main objective of diversifying the economy and reducing the kingdom's reliance on oil revenues. Among its many goals, it aims to enhance women's participation in the labour force from today's 22 per cent ${ }^{68}$ to 30 per cent by $2030 .{ }^{69}$

These women-accommodating reforms can be compared to similar changes in Iran, which sociologist Nazanin Shahrokni describes as a shift in modalities of state power, moving from prohibiting measures to productive ones. ${ }^{70}$ In her analysis of women and state power, Shahrokni applies Foucault's conception of power as a productive mechanism in governmentality, as opposed to governing as a sovereign power, in that it utilizes concrete "realities" to shape a problem-space to which power has the solution. ${ }^{71}$ She also draws on the work of John Meyer in understanding state power as "devolving from global (political) culture." 72 Here, Western liberalism is identified as becoming the hegemonic "world ideology" that states are expected to adopt and provide to their citizens. ${ }^{73}$ Examining the Iranian government's attitude towards women's outdoor exercise as a case in point, she demonstrates how the state went from prohibiting such activities to embracing and encouraging them by providing women-only parks as a solution to globally recognized health problems. This shift in state power modality can also be observed in the Saudi government's adapting to increase the presence of women in public. In Saudi Arabia, both liberals and Islamists view the state's patronage as being essential for strengthening their position in society. ${ }^{74}$ It is the state that provides both the necessary space and the financial resources for women to engage in the public sphere. Hence the relationship between the state and its

\footnotetext{
${ }^{67}$ Ministry of Education, "al-Ahdāf wa-al-siyāsāt li-khiț̣a al-tanmiya al- 'āshira [Objectives and Policies for the Tenth Development Plan],” الأهداف_و السياسات_لخطة_التنمية_العاشättp://www.dppedu.gov.sa/archives/of_files ed. General Directorate for Planning and Policies Ministry of Education (Ministry of Education, 2015).

${ }^{68}$ The percentage of female participation in the labour force was 20.2 in 2013, the lowest rate in the Arabian Peninsula and less than half compared to the other Arab Gulf states. The World Bank, "Labor Force Participation Rate, Female," The World Bank Group, http://data.worldbank.org/indicator/SL.TLF.CACT.FE.ZS/countries/SAKW-OM-BH-YE-AE-IR?display=graph.

69 "Full Text of Saudi Arabia'S Vision 2030," Saudi Gazette, 26 April 2016, http://saudigazette.com.sa/saudiarabia/full-text-saudi-arabias-vision-2030/.

${ }^{70}$ Nazanin Shahrokni, "The Mothers' Paradise Women-Only Parks and the Dynamics of State Power in the Islamic Republic of Iran," Journal of Middle East Women's Studies 10, no. 3 (2014): 87-108, doi: 10.2979/jmiddeastwomstud.10.3.87.

${ }^{71}$ Ibid., 91-92.

72 Ibid., 92.

${ }^{73}$ Ibid., 92, 100.

${ }^{74}$ Madawi al-Rasheed, A Most Masculine State, 142.
} 
subjects is increasingly becoming one of governmentality. Therefore, and in order to fully

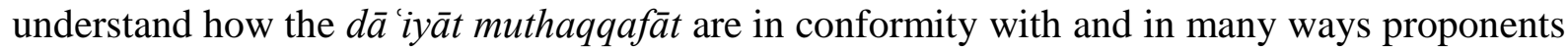
of the political leadership, one also has to examine the dimensions of Saudi Arabia's field of power $^{75}$ and where dā iyāt muthaqqafāt place themselves in relation to such power. As Lacroix notes, both the political field - which consists primarily of the royal family - and the religious field, containing traditional religious scholars, can be placed within the field of power. $^{76}$

\section{Ihtisāb: from prohibition to accommodation - reflecting the shift in state power}

The dā'iyāt muthaqqafāt see themselves as guardians of the religious character of the kingdom, where they both perform the role of "checks and balances" on the political leadership's upholding of $\operatorname{sharī~}^{\prime} a$, and a form of "executive branch" of the religious affairs. They find the legitimation of these roles in the concept of ihtisāb. One event that demonstrated this was the inauguration ceremony of $a l-H u s n \bar{a}$, an association describing itself as the first scientific association for Islamic studies for women in the kingdom. ${ }^{77} \mathrm{Al}-\mathrm{Husna}$ consists of many intellectual female preachers, such as Ruqayya al-Nayyāz and Najlā' alMubārak. Opened by Princess Ḥișșa, the daughter of King Salmān, the ceremony was profoundly dedicated to exalting the kingdom's continuous efforts in the works of da wa. Patriotic poems were read in praise of the royal family, before everyone stood up to chant the national anthem. After the princess's speech, a group of young women appeared on the stage with a choreographed performance during which they sang and read pieces of poetry about Islam and about their love for the country and $\overline{\mathrm{A}} \mathrm{l} \mathrm{Sa}$ ùd, while heroic pictures of the king were screened in the background. What was remarkable about the ceremony was the way these women placed themselves, and the work they performed in $d a$ ' $w a$, in relation to the political governance itself. Immediately after showing a video clip in which the king proclaimed that Saudi Arabia is a state of tawhìd and da'wa, a woman's voice was transmitted, vowing that women would uphold this cornerstone of the state with their own

\footnotetext{
${ }^{75}$ A concept taken from Pierre Bourdieu's social theory in which the field of power is an amalgamation of all fields that have a power over social fields. Since some fields are more dominant than others, a hierarchy exists where some fields are often dependent on activity in another. According to Bourdieu, the structure of a field is a state of the power relations among the agents or institutions engaged in the struggle. The struggle is for the monopoly of legitimate violence, or authority. Patricia Thomson, "Field," in Pierre Bourdieu: Key Concepts, ed. Michael James Grenfell (London, New York: Routledge, 2014), 56-81; Pierre Bourdieu, Sociology in Question (London: Sage, 1993), 72-77.

${ }^{76}$ Lacroix, Awakening Islam, 7.

77 al-Ḥusnā, "al-Nashra al-ta rīfiyya [Introductory Pamphlet],” ed. al-Ḥusnā (Riyadh: al-Ḥusnā. Saudi Association for Islamic Studies, 2016).
} 
da'wa efforts. ${ }^{78}$ Going back to Foucault's concept of power as a productive mechanism in governmentality, ihtis $\bar{a} b$ can thus also be understood as a power that is shifting its mode in its understanding of female participation in the public sphere from prohibitive to productive, as dā 'iyāt muthaqqafāt insist on their own inseparable relationship with state power.

With the advent of the Internet, and the introduction of social media, intellectual female preachers' messages have the potential to permeate Saudi society more widely than before, as well as to cut across traditional gender segregation. Before the advent of new media, religious gatherings were announced in mosques and within existing religious circles consisting of family, friends, and neighbours. The religious activities of the female preachers were therefore not as easily accessible to those who were outside of these networks. In addition, one had to be physically present. Today, many of these lectures are simultaneously streamed online, broadcast on Youtube, and recorded on mobile phones by women attendees. Furthermore, whereas the first religious websites and internet forums, such as Lahā Online, were intended for women and therefore contained feminine content and graphic design that, according to Le Renard, reinforced already existing homosocial relationships, social media has opened up for virtual platforms that are less gender specific, where both men and women engage together. ${ }^{79}$ Even those who uphold the strictest interpretation of the concepts of khalwa and 'awra, an interpretation which has until recently restricted physical heterosociality to absolute necessities, can now join the public sphere, where both men and women are the potential recipients of their message, without having to jeopardize their convictions. While khalwa is generally understood as the forbidden physical seclusion of a man and woman, 'awra includes the parts of a woman or a man that are forbidden for the opposite sex to see. This is most palpable in the example of Sāra al-Mas ' $\bar{u} d$, who held the most strictest view of women's role in society among the preachers I met. She contended that a woman's voice is 'awra and called for a maximalist interpretation of women's dress code to include the covering of hands with gloves in addition to the head 'abāya and full face veiling. ${ }^{80}$ Yet al-Mas 'ūd has Twitter, WhatsApp, Instagram and Snapchat accounts, where she publishes literal religious content. She argues that social media applications are permissible so long as one does not become too informal with the opposite gender or send private text messages and thus engage in khalwa. ${ }^{81}$ Social media have thus also provided an additional platform to the already existing literary outlets, for even the more ultra-orthodox and

\footnotetext{
${ }^{78}$ Personal observation, Riyadh, 27 January 2016.

${ }^{79}$ Le Renard, "From Qur'anic Circles to the Internet," 118-119.

${ }^{80}$ Interview by author, 30 August 2016.

81 Ibid.
} 
peripheral preachers to engage in discussions where the potential public consists of both women and men. However, social media have their limitations. As noted by 'Abd al- Raḥmān al-Shuqayr, a social scientist and writer of a $\mathrm{PhD}$ thesis on Bourdieu's cultural capital among Saudi youth, participants in social media platforms often tend to remain within their own field by following like-minded people and thus reproduce the milieu that they already belong to. ${ }^{82}$ Nevertheless, social media have provided unparalleled opportunities for female preachers to both coordinate their activities and convey their message outside of their traditional circles, all in a timely and sophisticated way that manifests their relevance in contemporary "global culture."

In what follows, I will examine how dā'iyāt muthaqqafāt regard women's participation in the workforce and how they respond to what is arguably the most contentious issues in this matter: gender roles and gender mixing (ikhtilat t). An analysis of the thoughts of Nawāl al-' $\bar{I} d$ as an example of these women will hopefully give further insight into how the positions advocated by da 'iyāt muthaqqafāt have shifted (from preventing to producing in the public sphere) and how the opportunities provided by the state have necessitated an adaptive approach to contemporary realities. In addition to being essential for the emancipation of women, it is this area that has increasingly opened up for women in recent years.

\section{Working women as a wish (raghba), not as a need (häja)}

As the state seeks to gradually incorporate women into the workforce, two issues in particular continue to resurface as focal points of contention: traditional gender roles and gender mixing (ikhtilatt). The intellectual female preachers do not see a woman working outside the home as a problem in itself, although they maintain that it comes second to her obligations at home. ${ }^{83}$ Nawāl al- 'Id sets down eight general rules that a woman must abide by if she chooses to work outside of her home: ${ }^{84}$

(1) She must have the permission of her male guardian, unless he refuses to let her work as a means of suppressing her or from getting her needs fulfilled. In this case, he has no right to prevent her.

(2) Work should not delay her from getting married.

(3) Work should not delay her from having children.

\footnotetext{
${ }^{82}$ Interview by author, 17 September 2016.

${ }^{83}$ A woman's obligations in her home are regarded as more important than even da'wa activities outside the house. A former $d \bar{a}$ ' $i y a$ told me that she stopped being as active as she used to be because she had to prioritize her home. She applauded women who dedicated their lives to $d a$ ' $w a$, but at the same time expressed her concern that their exaggerated focus in $d a^{\prime} w a$ meant that their domestic duties were neglected. Dā'iya, interview by author, 23 February 2016.

${ }^{84}$ al- '⿳亠'冋d, Huqūq al-mar'a fì ḍaw' al-sunna al-nabawiyya, 895-905.
} 
(4) It cannot come at the expense of the well-being of her husband or children.

(5) The work itself cannot contradict Islamic rulings, such as working with interest (ribā).

(6) It has to be compatible with her biological nature so that it does not harm her.

(7) Her clothing must be "modest", in the sense of completely covering her body; and

(8) The work must not lead to khalwa or ikhtilät.

At first glance, these preconditions can be perceived as discouraging women from working, but a closer look at how she defines the nature of labour indicates a need to protect traditional women's interests in an environment perceived as being challenged by "global culture."

Throughout her work, al- ' $\overline{\mathrm{I}} \mathrm{d}$ emphasizes that women are not supposed to be working for economic reasons, because men are responsible for providing for women. ${ }^{85}$ In her book, she introduces the topic by arguing that today's gender debates has Western historical roots going back to the French Revolution and the emergence of a bourgeoisie in need of a cheap workforce, a workforce that was found in poor rural women who were desperate to obtain a means to live in urban cities. The starting point, she contends, is therefore one of exploiting women's needs, a situation that continues in today's Western countries, where fathers do not have economic responsibility for their daughters after the age of 18. She accuses Western men of being stingy and selfish for refusing to provide for those who do not contribute financially. ${ }^{86}$ Rather, she asserts that women should join the labour force due to a wish (raghba) to contribute to society at large rather than due to an economic need (hāja) ${ }^{87}$ If the latter is the case, she asserts, then men's obligation under Islamic law to provide for women (nafaqa) is violated (or the state's is, in cases where a woman lacks a husband, father, or brother to support her). ${ }^{88}$ This, she contends, is the only way women can be protected from being exploited by men who are in need of a cheap workforce. With this view, she also departs from the prevalent social feminist perception, which views economic forces as one of the main push factors for women's access to education. ${ }^{89}$ Female labour is, in addition, regarded as constituting a threat to the value of domestic work which, she argues, is at least as important as the work done in the public sphere, "because women work as teachers, nurses,

\footnotetext{
85 “Kalima al-duktūra Nawāl al- 'Īd fī multaqā al-mar'a al-sa ūdiyya [Speech of Nawāl Al 'īd in Saudi Women Forum]," Youtube video, posted $\quad$ 06.03.2014, https://www.youtube.com/watch?v=90_0bqcEejc.

${ }^{86}$ al- 'İd, Huqūq al-mar'a fì daw' al-sunna al-nabawiyya, 871-75.

87 “'Amal al-mar'a [Women's Work]," Youtube video, posted by Nawalal3eedAudio, 04.02.2013, https://www.youtube.com/watch?v=TM2vt55jFnM.

88 "Kalima al-duktūra Nawāl al- 'Īd fì multaqā al-mar'a al-Sa 'ūdiyya".

${ }^{89}$ Nelly P. Stromquist, "Gender Inequality in Education: Accounting for Women's Subordination," British Journal of Sociology of Education 11, no. 2 (1990): 137-53, doi:10.1080/0142569900110202.
} 
economists, psychiatrists, and administrators inside their homes. ${ }^{90}$ Female liberals who call for greater participation of women in the labour force are accused of undermining the crucial work of fostering and developing the future generation which al- ' $\bar{I} d$ demands must be given greater acknowledgement. She also points to the potential outcome of women having to work twice as much as men if they lose their right of being provided for financially through men's obligation of nafaqa and thus having to work both outside and inside their homes because of economic needs. At the same time, she criticizes the state for failing to facilitate and support women who wish to work part-time and asks why the labour sector is not doing more to accommodate working women, such as allowing them an hour off to breastfeed their infants. ${ }^{91}$

How al-' $\bar{I} d$ argues against ikhtilāt at work and school highlights some important aspects of the ongoing discursive shift from prohibition to production. Although she, in effect, insists on prohibiting gender mixing, she is at the same time calling for the production of larger spaces for women's participation in public life without compromising on their commitments to a perceived pious lifestyle. For example, she says that ikhtilat t would lead to a curbing of their freedom in being able to walk without the 'abāya and niqāb in their places of work and study. ${ }^{92}$ This aspect was highly observable at different religious gatherings. Once, in a lunch break during a lecture with al-Muhārib, the women complained about how so-called liberal women, with their demand for ikhtilāt, want to deprive them of their freedom to dress how they wish to. ${ }^{93}$ Al-Muhārib mentioned the difficulty of sitting for hours with their faces veiled in a Qur' an conference they had recently attended in Morocco and expressed gratitude for how Saudi Arabia accommodated women through gender segregation.

Another interesting aspect of segregation is that it creates appropriate platforms for conservative women to see and be seen. As Le Renard observes in her study of urban Saudi women, "consumerist femininity," through the possession of international top brands and the

\footnotetext{
90 "Kalima al-duktūra Nawāl al- 'Ĩd fī multaqā al-mar'a al-Sa'ūdiyya”. This view is interestingly in line with Bourdieu's theory of masculine domination in which he explores the historical structures of unconscious schemes of perceptions which have led to the sexual division of labour and thus the "objective consensus" of domestic work as being less valuable than non-domestic work, women thereby losing out from not being awarded in terms of material goods. Pierre Bourdieu, Masculine Domination (Stanford, Calif.: Stanford University Press, 2001), 98.

91 "al-Musāwā bayn al-jinsayn barnāmij nawāfidh usariyya [Equality between the Sexes. Program: Family-elated Benefits]," Youtube video, posted by Nawalal3eedAudio, 18.02.2013, https://www.youtube.com/watch?v=DQZ89e6kqqs. In Norway, the same demand was championed by women's rights activists. In the current Working Environment Act, nursing mothers are entitled to have up to one hour paid time-off to breastfeed during the child's first year. Directorate of Labour Inspection, "Work Environment Act," ed. Directorate of Labour Inspection (Trondheim: Directorate of Labour Inspection 2015), http://www.arbeidstilsynet.no/binfil/download2.php?tid=92156.

92 "Shubuhāt ḥawl al-mar'a [Suspicions Regarding Women]," Youtube video, posted by Nawalal3eedAudio, 15 April 2013, https://www.youtube.com/watch?v=vNYFIFCjhcg.

${ }_{93}$ Conversation with author, 12 November 2015.
} 
ability to look "stylish", is an important aspect of self-presentation among young women. ${ }^{94}$ The cultivation of global femininity is so prominent that even preachers wear make-up and conform to a "Westernized" dress code. By conforming to consumerist femininity, they assert their relevancy in contemporary Saudi female society at the same time as they seek to maintain the acceptable space of this self-presentation. The look of a $d \bar{a}$ iya is so important that it is even incorporated into da'wa literature. According to al-Mas ' $\bar{u}$, "the appearance and beauty of a da' 'iya captivates the listeners because humans are naturally disposed to loving what is beautiful." 95 However, this does not mean that all showcasing of femininity is seen as acceptable. I experienced this during my first attempts to adhere to what I thought was the appropriate dress code in the different religious gatherings. The first time I attended one of al'I $\mathrm{d}$ 's lectures, I kept both the hijāb and the 'abāya on, but realized very soon that I was one of very few women still covered. The next time a conference was held, I showed up with a long tunic and trousers; during the lunch break with al-Muhārib, she gently suggested the inappropriateness of wearing trousers by telling me that "all the girls are asking about who the girl with the pants is." When I asked her if it was forbidden to wear trousers, she responded that these girls are "seekers of knowledge" (țälibät al- ilm), implying that the dress code of a student of religious studies had to reflect a certain type of "religious modesty" that deemed trousers inappropriate. ${ }^{96} \mathrm{An}$ additional aspect of self-presentation in religious circles is therefore to showcase a femininity that at the same time conforms to an envisioned modesty. This is because, as Mahmood argues, the external aspects of religiosity is an indispensable part of cultivating piety among female preachers due to the effects that outward practices have on the acquisition of inner belief itself. ${ }^{97}$

Another key concern regarding ikhtilat th that it is perceived as being a threat to marital harmony, which might be jeopardized by wider access to the opposite gender, in addition to being a door-opener to sexual harassment. ${ }^{98}$ Another concern raised is that job opportunities for women might be reduced if women have to compete with men for the same positions, because men are generally favoured in the public sphere. ${ }^{99}$ Opposition to ikhtilat $t$ is therefore not because women such as al- ' $\bar{I} d$ are against women working outside their homes but because they fear losing privileges - or, in al- '̄id's words, rights - conservative women

\footnotetext{
${ }^{94}$ Amélie Le Renard, A Society of Young Women: Opportunities of Place, Power, and Reform in Saudi Arabia (Stanford, CA: Stanford University Press, 2014), 131-37.

${ }^{95}$ al-Mas 'ùd, Kayfa takūninna dā 'iya, 81.

${ }^{96}$ Some da 'iyāt also consider pants to be prohibited because, in addition to revealing the 'awra of a woman, it is also argued that they go under the prohibition of imitating men and non-believers.

${ }^{97}$ Mahmood, Politics of Piety, 155-61.

98 al- 'İd, "Shubuhāt ḥawl al-mar'a".

99 Ibid.
} 
enjoy in today's Saudi Arabia. By arguing for more segregated spaces, these women have shifted from the traditional approach, which prohibits women from working outside of their home, to seeking to accommodate their engagement in the public sphere.

In these physically segregated spaces, women do engage with men in a variety of discussions, but in separate rooms using audio transmission. Ithrā', Nawāl al-'Īd's foundation, stands behind many of these initiatives. Inaugurated in 2015, it aims to become a leading organization in promoting "comprehensive developments" for women and families on local and global levels. ${ }^{100}$ This includes initiating different programmes to tackle women's issues, enabling women in the service of religion and nation, deepening cooperation with governmental and private organizations, and supporting scientific research on women and family issues. ${ }^{101}$ One event I attended that underscores the dynamics and sophistication of these women was a conference entitled Mubta itha ("The Dispatched Student"). ${ }^{102}$ Targeting women studying or intending to study abroad, the conference's overall message was extraordinary coming from traditional religious figures. It encouraged women to travel to non-Muslim countries for the purpose of gaining the experience and empowerment necessary to contribute to the development of the country. Late scholars such as Ibn Bāz and Ibn al'Uthaymin, to whom these women often refer, had a more restrictive attitude, according to which they even cautioned men against travelling to "the lands of infidels" (bilād al-kuffār), unless there was a pressing need and provided that the faith of the traveller was well protected. ${ }^{103}$ For the conference to even encourage women to travel abroad is therefore unprecedented. With 500 women attending and over 70,000 listeners through live streaming, it was considered a huge success, and a follow-up has been launched under the banner of realizing the goals of Saudi Vision 2030. ${ }^{104}$ The event was quite creative, using new technology and different performances by the two young women who hosted the programme and entertained the audience with various surprises throughout the evening. The speakers comprised women and men (through video transmission) who shared their expertise and

\footnotetext{
${ }^{100}$ Hayā’ al-Dakkān, "Bi-l-Șuwar...dā iyāt wa-akādīmiyāt yushārikna "Nawāl al- 'Īd" fĩ iftitāḥ waqf "Ithrā' alMa rifa" [In Pictures...Preachers and Academics Join "Nawāl al- 'İd" in the Inaguration of "Ithrā' al-Ma rifa"]," Twasul, 25 October 2015, http://twasul.info/295245/.

101 "Ithrā" al-ma'rifa 1437h," Youtube video, posted by Ithra, 1 June 2016, https://www.youtube.com/watch?v=kWHdzyHjcfE\&t=5s.

102 "Mubta itha." Paper presented at the Mubta itha, Riyadh, 2 January 2016.

103 Muḥammad S. al-'Uthaymīn, "Shurūṭ al-safar ilā bilād al-kuffār li-l-dirāsa [Conditions for Traveling to the Lands of Infidels for the Purpose of Study]," www.islamqa.info, https://islamqa.info/ar/10175; 'Abd al- 'Azīz bin Bāz, "Huukm al-safar ilā bilād al-kuffār li-l-dirāsa [Legal Opinion on Traveling to the Lands of Infidels for the Purpose of Study]," www.binbaz.org, http://www.binbaz.org.sa/fatawa/203.

${ }^{104}$ Nawāl al- ' $\bar{d} d$, Twitter Post, 7 January 2016, https://twitter.com/Nawal_Al3eed /status/685190258330349568; Ithrā', "Mubta 'itha. Qiyam wa- 'imārat arḍ [Dispatched (Student). Value and Cultivation of Earth]," Ithrā', 2016, http://course.demo.innokeen.com.
} 
experience of studying abroad. For example, one exchange student who had been living with a British host family recollected it as a unique experience that gave him a deep social insight into British life and such a close tie with the host family that he now even considered them as his own family. The conference's programme was divided into three main sections: identity

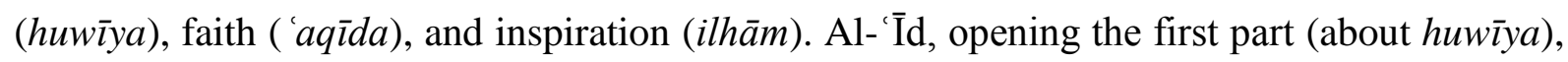
held an encouraging talk about how aspiring exchange students should build strength and confidence in knowing that they are ambassadors of both Saudi Arabia and Islam to the outside world. For example, she warned them of even thinking that veiling the face covers their thoughts and mind, and exclaimed: "We refuse to be an isolated island, as if we are but a dot in the ocean. Instead, we claim to be an integrated part of this world!" She then proceeded in answering some challenging questions one could face about Islam and Saudi Arabia, which she blamed on prejudices that have become widespread following the terror attacks of 9/11. She went through different ways to respond to questions such as religious freedom, women's inheritance in Islam, and extremism, and emphasized that the students must speak in a language that makes sense to people who do not belong to their faith. Her talk concluded with a powerful expression that summarized her overall message: "Our language is Arabic, our roots are heavenly, and our identity is humanity" (lughatunā 'arabiyya, judhūrunā samāwiyya wa huwīyatunā insāniyya).

\section{Concluding remarks}

The Ithrā' conference gives a vibrant glimpse into how da 'iyāt muthaqqafāt insist on playing a role in the changes in contemporary Saudi society by placing themselves within the field of power. As a result, and due to other reasons, they are also affected by the language of global culture in order to prove their relevance. Their shift from prohibition to production could therefore only be realized by expanding their roles as $d \bar{a}$ ' $i y \bar{a} t$, and its doctrinal justification $i h t i s \bar{a} b$, to include an engagement in the public sphere. This insight necessitates a revision of the literature that regards Saudi women in general, and female preachers in particular, as being excluded from the overall public sphere. By failing to give adequate attention to the dynamics of the official interpretation of religion that both affects and is affected by the context, the academic literature has mostly dismissed Saudi $d \bar{a}$ ' $i y \bar{a} t$ as having no role but to preserve overall male dominance. Such a one-dimensional description of the dā iyāt is inaccurate and misleading, and ignores the increasingly proactive role of female Saudi preachers. True, they do work and conduct their public discourse within a societal order which is still highly conservative and patriarchal, and in general they support the current 
governing system in the kingdom. However, by working within the system and by demonstrating a commitment to an ultraconservative lifestyle, they are well-placed to make their impact. The women in my case study possess religious capital as preachers but they are also professionals in religious studies and teach religious subjects in institutions of higher education. This dual capital equips them with the tools and authority to gain powerful positions not only within the traditional women's field but also beyond. As I have argued, the dā 'iyāt muthaqqafät have begun to play a role in the overall social sphere, which has been made possible by the transferable nature of the capital they have acquired from the religious field. They approach issues close to their heart pragmatically, incorporating elements of global culture in which a Western liberalist discourse is hegemonic, seeking to maximize the impact of their conservative message. This is evident in their approach to contentious issues in Saudi society, such as gender segregation and working women. Instead of resisting women's emancipation, they adapt to new situations by producing appropriate platforms of engagement. The dā 'iy $\bar{a} t$ 's approach is to promote "alternative" emancipatory projects and embrace a "productive appropriateness". By doing so, they depart from classical arguments about prohibitions. In this context, the example of the Mubta itha conference held for young women considering studying abroad, including in non-Muslim countries, is a case in point. Instead of relaying the traditional opinions of the late scholars Ibn Bāz and Ibn al-'Uthaymīn about restrictions on both men and women's travel, they promote a more encouraging attitude, viewing education abroad as an opportunity for women to contribute as productive citizens in their country and the Muslim world at large. It is also in this context that Saudi $d \bar{a}$ 'iyāt's insistence on gender segregation should be understood. By resisting ikhtilāt, they are demanding the opening of spaces that accommodate their presence outside the family home without compromising on a commitment to a conservative religious lifestyle. 